\title{
In situ guided tissue regeneration in musculoskeletal diseases and aging
}

\section{Implementing pathology into tailored tissue engineering strategies}

\author{
Franz Jakob • Regina Ebert • Maximilian Rudert • \\ Ulrich Nöth • Heike Walles • Denitsa Docheva • \\ Matthias Schieker • Lorenz Meinel • Jürgen Groll
}

Received: 3 June 2011 / Accepted: 1 September 2011 /Published online: 20 October 2011

(C) The Author(s) 2011. This article is published with open access at Springerlink.com

\begin{abstract}
In situ guided tissue regeneration, also addressed as in situ tissue engineering or endogenous regeneration, has a great potential for population-wide "minimal invasive" applications. During the last two decades, tissue engineering has been developed with remarkable in vitro and preclinical success but still the number of applications in clinical routine is extremely small. Moreover, the vision of population-wide applications of ex vivo tissue engineered constructs based on cells, growth and differentiation factors and scaffolds, must probably be deemed unrealistic for economic and regulation-related issues. Hence, the progress made in this respect will be mostly applicable to
\end{abstract}

F. Jakob $(\bowtie) \cdot$ R. Ebert $\cdot$ M. Rudert $\cdot$ U. Nöth

Orthopedic Center for Musculoskeletal Research,

Julius Maximilians University of Wuerzburg,

Brettreichstrasse 11,

D-97082 Wuerzburg, Germany

e-mail: f-jakob.klh@mail.uni-wuerzburg.de

R. Ebert

e-mail: r-ebert.klh@uni-wuerzburg.de

M. Rudert

e-mail: m-rudert.klh@uni-wuerzburg.de

U. Nöth

e-mail: u-noeth.klh@uni-wuerzburg.de

H. Walles

Institute for Tissue Engineering and Regenerative Medicine,

Julius Maximilians University of Wuerzburg,

Röntgenring 11,

D-97070 Wuerzburg, Germany

e-mail: heike.walles@uni-wuerzburg.de a fraction of post-traumatic or post-surgery situations such as big tissue defects due to tumor manifestation. Minimally invasive procedures would probably qualify for a broader application and ideally would only require off the shelf standardized products without cells. Such products should mimic the microenvironment of regenerating tissues and make use of the endogenous tissue regeneration capacities. Functionally, the chemotaxis of regenerative cells, their amplification as a transient amplifying pool and their concerted differentiation and remodeling should be addressed. This is especially important because the main target populations for such applications are the elderly and

D. Docheva $\cdot$ M. Schieker

Experimental Surgery and Regenerative Medicine,

Ludwig Maximilians University Munich,

Nußbaumstrasse 20,

D-80336 München, Germany

D. Docheva

e-mail: Denitsa.Docheva@med.uni-muenchen.de

M. Schieker

e-mail: Matthias.Schieker@med.uni-munechen.de

L. Meinel

Chair for Pharmaceutical Technology, Julius Maximilians

University of Wuerzburg,

Am Hubland,

D-97074 Wuerzburg, Germany

e-mail: 1.meinel@pharmazie.uni-wuerzburg.de

J. Groll

Department and Chair of Functional Materials in Medicine and

Dentistry, Julius Maximilians University of Wuerzburg,

Pleicherwall 2,

D-97070 Wuerzburg, Germany

e-mail: juergen.groll@fmz.uni-wuerzburg.de 
diseased. The quality of regenerative cells is impaired in such organisms and high levels of inhibitors also interfere with regeneration and healing. In metabolic bone diseases like osteoporosis, it is already known that antagonists for inhibitors such as activin and sclerostin enhance bone formation. Implementing such strategies into applications for in situ guided tissue regeneration should greatly enhance the efficacy of tailored procedures in the future.

Keywords In situ guided tissue regeneration - Stem cells . Scaffolds $\cdot$ Regenerative medicine $\cdot$ Mesenchymal tissues

\section{Introduction}

Regenerative medicine is a rapidly developing field that represents a shift of paradigms with respect to the principal goals of medical treatment. The main goal of former therapeutic strategies, the functional enhancement of tissues as they are, is gradually being replaced by new strategies to regenerate tissues and organs (Bernardo et al. 2011; Malchesky 2011). Two main strategies have been followed during the last two decades with respect to tissue regeneration.

One is the ex vivo construction and transplantation of new tissue, based on the triad of autologous cells, factors and scaffolds. Remarkable progress has been made with respect to in vitro fabrication of substitutes for tissues and organs grown in bioreactors, which can be transplanted into tissue defects (Rouwkema et al. 2011). For example, children with congenital bladder abnormalities have been successfully treated with cytoplasty using engineered bladders, created with autologous cells seeded on collagen-polyglycolic acid scaffolds (Atala et al. 2006). Also, impressive casuistic examples are the transplantation of segments of esophagus or bronchus, some reports being based on the decellularized and reseeded matrix "biovasc" (Omori et al. 2005; Walles et al. 2005). Other artificial tissues grown in vitro are liver and heart but none of these complex constructs - although of great perspective- has yet achieved the stage of routine clinical applications (Mertsching et al. 2009; Walles et al. 2005). In the field of musculoskeletal diseases, material and scaffold development has strongly focused on the generation of mechanically stable three dimensional structures with controlled micro- and macroporosity (Hutmacher 2000) and recent developments aim at the construction of hierarchical constructs through the application of multiple printing of hybrid systems (Schuurman et al. 2011). Overall, progress has mainly been made in the fabrication of bone inductive scaffolds, cell-based cartilage replacement and ligament/ tendon replacement using artificial scaffolds or natural autografts (Bernardo et al. 2011; Kirker-Head et al. 2007;
Levi and Longaker 2011). Controlled clinical trials are, however, lacking and it is only now that the first clinical trials on cell-based bone and cartilage regeneration are under way (http://www.vascubone.fraunhofer.eu/index. html).

The second strategy is in situ guided tissue regeneration or in situ tissue engineering - occasionally also termed "endogenous regeneration"-which aims to stimulate the intrinsic potential of a tissue to heal or regenerate (Uebersax et al. 2009). Endogenous stem cell homing and retransplantation of ex vivo amplified precursors have been addressed as a means of in situ tissue engineering as well as the engineering of new, partially functionalized scaffolds especially for bone tissue engineering, among them also injectable scaffolds for regeneration induction (Chen et al. 2011; Grafahrend et al. 2010, 2011; Pennesi et al. 2011; Shekaran and Garcia 2011; Uskokovic and Uskokovic 2011).

This review will demonstrate the present achievements and future perspectives of in situ guided tissue regeneration strategies in the field of musculoskeletal diseases. We will focus on classical mesenchymal tissues and on future tailored approaches in diseased and elderly organisms.

\section{In situ guided tissue regeneration applications - past and present}

Bone healing and regeneration has been addressed in numerous casuistic applications but so far only a few non-randomized trials in humans using scaffolds, soluble factors and autologous skeletal precursor cells, either in combination or as single tools, have been performed. Effects on the healing of critical size bone defects have been seemingly demonstrated but there is no randomized controlled clinical trial that compares the gold standard of autograft bone transplantation versus in situ guidance of tissue healing. Although there are numerous preclinical studies, a convincing standard method is still missing (Cooper et al. 2010; Gomes and Fernandes 2011; Horner et al. 2010). The transplantation of stem cells in osteonecrosis after intensive chemotherapy, osteonecrosis of the jaw associated with bisphosphonates and in avascular necrosis of the femoral head has been successful in casuistic applications by our group and others (Cui and Botchwey 2010; Hauzeur and Gangji 2010; Hernigou et al. 2005; Kikuiri et al. 2010; Lee and Goodman 2009; Muller et al. 2008; Noth et al. 2007). While the rare entities are hard to evaluate in randomized trials, there is the chance in avascular necrosis of the femoral head and such clinical trials are under way. New regulations by the authorities like the EMA, however, challenge these 
applications as routine population-wide strategies of treatment (Mertsching and Walles 2009).

Tissue specific applications of cells with and without scaffolds and factors

Over recent years, many studies about local or systemic applications of skeletal precursors as well as crude bone marrow-derived cell populations have been reported in various preclinical and clinical set-ups. Mesenchymal stem cell (MSC) populations have been applied in indications like myocardial and cerebral infarction, avascular necrosis of the femoral head, critical perfusion in diabetic angiopathy, nonunion/compromised bone healing, post-transplantation graft versus host disease and inflammatory autoimmune situations like rheumatoid arthritis and lupus erythematodes (Jones and Yang 2011; Menasche 2011; Singer and Caplan 2011; Tyndall and Houssiau 2010; Wu et al. 2011a). In none of these situations has there been convincing proof whether or not MSC by amplification and differentiation to a relevant extent participate in healing and regeneration, or if the effect was solely due to transient stimulation of resident regenerative cells by the secretome of the precursors applied (e.g. of proangiogenic and other growth factors). Functional enhancement of target tissues seemed to have been plausible but controlled randomized studies are rare. In bone lesions, the stimulatory effect on the healing of pure MSC application into critically injured regions has been demonstrated no matter what the cellular mechanisms are (Fan et al. 2010; Flynn and O'Brien 2011; Li et al. 2011; Muller et al. 2008; Noth et al. 2007; Zhao et al. 2010).

Cartilage has a very low regeneration capacity in adults and the cell-based applications for cartilage replacement cannot be addressed as classical in situ guided regeneration. If at all, the criteria of in situ tissue engineering apply for autologous chondrocyte transplantation. The result of this procedure is not hyaline but fibrous or at best hyaline-like cartilage, which functionally does not replace hyaline cartilage (Bedi et al. 2010; Benthien et al. 2011; Hildner et al. 2011). This topic is also being addressed in a separate issue of this journal.

Tendon regeneration and healing would be an important issue for partially ruptured tendons and in tendon degenerative disease. Hence, tendon degenerative disease has come into focus and research activities have recently begun to increase in this field, while new paradigms of thinking caused a switch from inflammation to degeneration as the underlying pathology. However, the process of tenogenic differentiation is not yet completely understood and the reversibility of such degenerative disease by using cell-based treatment strategies is a matter of research (Hogan et al. 2011; James et al. 2011; Liu et al. 2011; Warden 2009). For example, it has been shown that tendon and ligament tissue harbors its own stem/ progenitor cell population, which has some overlapping characteristics with the better known MSC (Bi et al. 2007; Docheva et al. 2010). GFP chimeric mouse models have also demonstrated that activated tendon-derived cells participate in the healing process, thus suggesting that the identification of algorithms to enhance the endogenous regeneration can be very suitable and fruitful for this type of tissue (Kajikawa et al. 2007). While it remains questionable whether degenerative disease can be reversed and regeneration and healing can be induced in such conditions, there is a remarkable clinical need for strategies to enhance and ameliorate the endogenous healing process in the situation of post-traumatic lesions like tendon tears or after pathological stretching.

\section{Material and scaffold developments}

Traditional implants and implant materials for load-bearing systems have been primarily developed with a focus to satisfy requirements of biocompatibility and replacing lost function and structure and perhaps more recently the focus was expanded to ease of handling. Clearly, pure titanium or stainless steel, titanium alloys with Molybdenum or Niobium, ceramics and non-degradable polymers are still the dominating materials in the sectors, particularly for fracture fixation and joint replacement where immediate stabilization/replacement of lost tissue function is required. Current optimization strategies addressing bone porosity within the host bone aim at integrating the aspect of vascular damage to the host tissue in response to the implantation, as was suggested decades ago (Perren et al. 1988). Implant coatings can be used to render the implant surface more biocompatible and to increase osseous integration, deliver antibiotics locally (e.g. to minimize pin-track infection; Fixateur externe) or to promote angiogenesis or tissue healing (e.g. growth factors or antibodies). Recent strategies aim at coatings that combine the promotion of cell adhesion and osseous integration with concurrent minimization of bacterial adhesion and biofilm formation (Bruellhoff et al. 2010; Groll et al. 2009).

One example for an interesting coating material that can be tuned for in situ regenerative properties is silk fibroin. It has been demonstrated that it can be blended with proteins known to increase biocompatibility such as hyaluronic acid (Garcia-Fuentes et al. 2009) and is efficiently protecting growth factors upon implantation while providing a continuous release into the implant zone (Wenk et al. 2011). Furthermore, the surface of silk fibroin scaffolds can be easily modified to satisfy local needs. For example, it has recently been demonstrated that surface charge is an effective approach to control growth factor localization, release and potency of growth factors from modified silk fibroin surfaces (Wenk et al. 2010). Similarly, the conformation of adsorbed fibronectin (Fn) 
to silk fibroin implants-Fn is an important component of the extracellular matrix-was recently characterized in more detail (Meinel et al. 2009).

Osteoinductive and osteoconductive materials have been used for in situ guided regeneration in various preclinical models and in part have found their way into clinical applications (Giardino et al. 2002, 2006; Kim et al. 2009; Krebs et al. 2009; Taguchi et al. 2005). Numerous developments have been performed towards injectable materials for bone regeneration (Kretlow et al. 2007). Such systems may be based on inorganic, organic or inorganic/ organic hybrid materials. Hydrogels have been one major area of research for the last decades (Lee and Mooney 2001) and induced by the pioneering work of Lutolf and Hubbell, a lot of attention has been laid on injectable hydrogel systems (Lutolf and Hubbell 2005). While such systems that may be tailored for enzyme specific degradation mechanisms, may be loaded with growth factors and in some cases do show extremely promising results regarding bone regeneration in animal experiments (Lutolf et al. 2003), their application for load bearing or critical size defects is at the moment not conceivable as these materials share insufficient initial mechanical stability.

\section{Principal obstacles of in situ guidance in the elderly and diseased}

Intrinsic stem cell deficits: availability and quality

of regenerative cells in aging and disease

Tissue healing and regeneration involves debris removal by the cells of the innate immune system, mainly by the monocyte/macrophage lineage and the simultaneous stimulation of resident regenerative stem cells, which in part seems to be exerted by the former. The rapidly developing knowledge about the role of monocyte/macrophage subspecies in stimulation of regeneration adds fascinating information about the regenerative process as such. In the case of mesenchymal tissues, the source of tissue-specific regeneration is skeletal precursors with a multipotent adult stem cell phenotype, resident in their respective and protected niches all over the organism. There has been a lot of discussion about the quality and availability of such cells throughout life, which is excellent in childhood but altered in the aged or diseased organism. Overall, a certain consensus has been achieved in that the number of available colony-forming cells is reduced with age but a considerable body of literature also describes age-related deficits in quality and function due to both extrinsic and intrinsic factors, the latter comprising certainly genetic background and epigenetic changes (Burtner and Kennedy 2010; Efimenko et al. 2011; Pollina and Brunet 2011; Sahin and Depinho 2010). Recent literature also indicates an important role of miRNAs on stem cell aging (Grillari and Grillari-Voglauer 2010). Hematopoetic stem cells are gradually reduced in number by age while the remaining ones are of acceptable although somewhat reduced quality (Brusnahan et al. 2010). Mesenchymal precursors in higher age and in osteoporosis appear to be impaired with respect to osteogenic differentiation and they prefer the adipogenic pathway of differentiation (Laschober et al. 2011). Recently, the expression of Maf, a basic leucine zipper transcription factor, has been described to be a critical switch in this age-related event (Nishikawa et al. 2010). We and others have shown that adipogenic transdifferentiation can be antagonized by FGF signaling in vitro (Schilling et al. 2008; Xiao et al. 2010) and this information could be introduced into future strategies of tissue regeneration. MSC from aged donors display a proinflammatory phenotype and are prone to replicative senescence and this can be partially rescued by p21 knockdown or exposure to a young extracellular matrix (Laschober et al. 2011; Sun et al. 2011; Yew et al. 2011).

In summary, there are solid data to demonstrate that at least for some tissues aging impairs the capacity of skeletal precursors to amplify, to migrate and to differentiate for intrinsic reasons as initiated by genetic background and epigenetic events. At least epigenetics, however, is of course also being triggered by extrinsic systemic and environmental events that characterize organismal aging. These data should have impact on tailored applications for tissue engineering and in situ guided tissue regeneration.

\section{Extrinsic inhibitory modulators of tissue regeneration}

Organismal aging is accompanied by changes in the systemic environment. Many of these changes are associated with organ dysfunction and underlying diseases. Most prominent examples are the changes in the hormonal milieu, which are accompanied by the insufficiency of gonads, e.g. the rapid onset of ovarian failure in menopause and the slow and gradual insufficiency of male sex hormone production. Loss of steroidal sex hormones, especially estrogens, has been known to be associated with bone loss and osteoporosis for several decades. Moreover, estrogen deficiency in close interaction with the wnt/frz signalling pathway causes loss of mechanosensitivity at least in osteogenic precursors. The molecular mechanisms of mechanotransduction are being gradually unravelled and there is also evidence for critical changes with age (Liedert et al. 2006, 2010; Ozcivici et al. 2010; Saxon et al. 2007; Temiyasathit and Jacobs 2010; Wu et al. 2011b). Individual susceptibility to such impairment is also determined by the ability of peripheral tissues to convert hormonal 
precursors by expressing key activating and inactivating p450 enzymes and dehydrogenases and this fact is probably severely underestimated.

Gonadal insufficiency, however, does not only result in loss of sex steroids but in a corresponding increase/decrease in peptides that are involved in the regulation of the gonads, the pituitary gland and the central nervous system. Prominent examples with relevance to tissue regeneration are ligands of the TGF $\beta$ superfamily of proteins like activins and inhibins. It has been known for a long time that activin A has important effects on stem cells in development and adult life tissue regeneration. Activin A inhibits osteogenic differentiation, although the exact molecular mechanism remains elusive, since constitutively activating mutations of its receptor ALKII/ACV1 causes the inherited rare disease of "fibrodysplasia osteoplastica progressive" FOP (Shore and Kaplan 2010; van Dinther et al. 2010). Preclinical studies in primates using an activin antagonistic recombinant fusion polypeptide (Koncarevic et al. 2010; Trivedi et al. 2010) demonstrated remarkable osteoanabolic effects. Similar data are being reported for the muscle regulator myostatin (GDF8). Myostatin levels rise in aging and osteoporosis (our unpublished results) and myostatin knockout causes an increase of muscle mass but also of bone mass and size at many sites (Hamrick et al. 2002, 2006; Morissette et al. 2009). These data also initiate compelling hypotheses as to the relevance of inhibitory peptides for tissue engineering and in situ guided tissue regeneration in both young but even more aged organisms.

Proinflammatory signaling and underlying diseases

Ageing is associated with a proinflammatory phenotype. Researchers in the field even coined the term "inflammaging". Proinflammatory signaling is mediated by the innate immune system and its receptors like the Toll-like receptor family but also by cells of the adaptive immune system such as certain $\mathrm{T}$ cell subpopulations that secrete proinflammatory cytokines (Laschober et al. 2011). Moreover, the spillover of reactive oxygen species caused by environmental circumstances and also by proinflammatory receptor signaling maintains this situation and directs it into a chronic inflammatory reaction. Talking about in situ guided tissue regeneration means to envision that chronic inflammatory environment impairs healing processes and may also exert commitment and conditioning of regenerative cells. Hence, expansion under conditions of low oxygen may represent one means of avoiding ROS spillover, although it remains to be proven if proinflammatory signatures are at least in part reversible (Fehrer et al. 2007). In this context, it is worthwhile mentioning that recent reports have shown that control of nanoparticle surface chemistry may be used to direct macrophage gene expression and surface antigen markers towards either proor anti-inflammatory phenotype (Bartneck et al. 2010). This indicates that nanotechnology may in future offer tools for immunmodulation that may become important in tissue engineering for aged patients.

In bone healing, inflammatory reactions of the innate immune system are part of the healing process and antiinflammatory drugs like NSAIDs may impair bone regeneration. Chronic inflammatory signalling as well as acute activation of the adaptive immune system by infections, however, may either cause impaired healing and non-union or even extraosseous un-organised calcifications. Bone healing is enhanced in the absence of the adaptive immune system, thus indicating that the activated system impairs regeneration and healing (Toben et al. 2011). The respective situations have to be discussed in the context of in situ guided tissue regeneration in the diseased organism and applications will have to be tailored to the diseased and the elderly (Fig. 1).

\section{Components of in situ guidance: the future}

Anatomical structure and artificial mimics in materials

Regeneration of complete limbs is a well-known phenomenon in lower organisms but not in humans (Jhamb et al. 2011; McCusker and Gardiner 2011). In the setting of in situ guided tissue regeneration, one would not need macroscopic but microscopic anatomical guidance in the nano- to micromolar range. Intelligent and functional materials may in future serve these goals of mimicking the microenvironment of regeneration from stem cell niches to tissue repair and remodeling according to developmental processes (Blau and Pomerantz 2011; Gavenis et al. 2010; Gilbert and Blau 2011; Gilbert et al. 2010; Grafahrend et al. 2011; Lutolf et al. 2009).

\section{Oxygen tension}

Oxygen tension within tissues is a very variable condition with respect to tissue-specific degree of vascularisation and also the degree of effective neoangiogenesis during regeneration and healing. It may be anticipated that low oxygen tension with a tendency to hypoxic conditions is common during regeneration after tissue injury. It may, however, also be assumed that low oxygen is prevailing in and around protected niches of regeneration. There is a considerable basis of literature on the effects of oxygen on the proliferation and differentiation capacity of various precursor cells including cancer (Keith and Simon 2007; Mohyeldin et al. 2010; Volkmer et al. 2008, 2010). Hypoxic conditions always induce factors like HIF-1alpha 


\begin{tabular}{|c|c|c|c|c|}
\hline $\begin{array}{l}\text { Oxygen } \\
\text { tension }\end{array}$ & low & low & $\begin{array}{c}\text { Intermediate / } \\
\text { high }\end{array}$ & \multirow{4}{*}{$\begin{array}{c}\text { Young } \\
\text { and } \\
\text { healthy }\end{array}$} \\
\hline $\begin{array}{l}\text { Inhibition of } \\
\text { differentiation }\end{array}$ & active & active & inactive & \\
\hline $\begin{array}{l}\text { Proliferation } \\
\text { activity }\end{array}$ & low & high & low & \\
\hline \multirow{3}{*}{$\begin{array}{l}\text { Migratory } \\
\text { activity }\end{array}$} & low & high & low & \\
\hline & & & 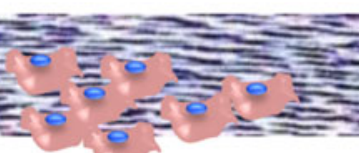 & \\
\hline & $\begin{array}{l}\text { Regenerative } \\
\text { stimulus, } \\
\text { asymmetric } \\
\text { cell division }\end{array}$ & $\begin{array}{l}\text { Transient } \\
\text { amplifying } \\
\text { pool }\end{array}$ & $\begin{array}{l}\text { Differentiation, } \\
\text { modelling and } \\
\text { remodeling }\end{array}$ & \\
\hline $\begin{array}{l}\text { Oxygen } \\
\text { tension }\end{array}$ & low & low & Inadequate & \multirow{4}{*}{$\begin{array}{c}\text { Aged } \\
\text { and } \\
\text { diseased }\end{array}$} \\
\hline $\begin{array}{l}\text { Inhibition of } \\
\text { differentiation }\end{array}$ & active & active & active & \\
\hline $\begin{array}{l}\text { Proliferation } \\
\text { activity }\end{array}$ & low & sufficient & low & \\
\hline $\begin{array}{l}\text { Migratory } \\
\text { capacity }\end{array}$ & low & impaired & low & \\
\hline
\end{tabular}

Fig. 1 Schematic and simplified depiction of a regenerative stimulus and some important changes in the microenvironment during the course of regeneration. Substantial differences between conditions in the healthy and young versus the aged and diseased organism are highlighted, like the constant expression of inhibitors of differentiation

that induce angiogenesis programs. The effect of low oxygen (around 3\%) conditions on musculoskeletal precursors has been reported to be in favour of proliferation of the transient amplifying pool but inhibits especially osteogenic differentiation and also to some degree inhibits the adipogenic pathway. Chondrogenic differentiation may even be enhanced under low oxygen conditions, hence the process of fracture healing might be directed towards the more complex way of callus formation and healing via chondrogenic pathways in conditions of low oxygen supply (Foldager et al. 2011; Henderson et al. 2010; Meyer et al. 2010). Only limited data are available according to ligamentogenic/tenogenic differentiation, although one should anticipate that low oxygen tension is also favourable (Liu et al. 2011; Zhang et al. 2010). As a consequence, the ex vivo amplification of skeletal precursors - if part of the strategy — should be considered to take place in 3\% oxygen such as activin, myostatin and sclerostin (see text) and altered migratory capacity, which impair effective regeneration. Future strategies in regenerative medicine should develop tailored applications accordingly

to allow for effective amplification and reduced ROS levels and cellular stress (Fehrer et al. 2007), while maintaining the broader spectrum of differentiation capacity.

Matrix and scaffold geometry and composition

It is essential for the amplification and differentiation efficacy to provide a suitable ECM until the respective cells have created their own. Natural matrices are very often provided but are also not really tailored to the purpose for which they are applied. This is of particular importance since cell differentiation is induced by certain ECM types and ECM-attached matricellular growth and differentiation factors (Pennesi et al. 2011). For example, the use of collagen type I for amplification and differentiation of cartilage precursors might not be ideal but has been used as a helpful matrix component while collagen II was not 
available. Also, the matricellular growth factors of the $\mathrm{CCN}$ family of proteins may exert differential effects during tissue differentiation and maintenance. Matrix from young and healthy cells added to cultures of skeletal precursors from aged donors can at least partially reconstitute their deficits in proliferation and osteogenic differentiation, indicating that their own matrix is not properly supporting their expansion and function (Sun et al. 2011). Finding important components that are lacking in the matrix of aged cells may allow for targeted substitution in future therapeutic strategies for the elderly. If artificial scaffolds are being used, there is a big chance of tailoring their specific composition and tethering with growth and differentiation factors for the requested clinical application (Gilbert and Blau 2011; Lutolf et al. 2009; Votteler et al. 2010).

\section{Micro-/nano-mechanobiology}

Not only matrix composition but also rigidity plays an important role, since it is known that stemness can more easily be maintained in soft matrices while stiff matrices tend to support differentiation (Gilbert et al. 2010). Adhesion to ECM components initiates mechanotransduction from the cell membrane to the nucleus. This is mainly mediated by mechanoresponsive elements such as AP-1 or SP-1 elements (Seefried et al. 2010). The sensitivity of a single cell to mechanical loading in the microenvironment depends very much on the amplification of the signal through actin skeleton-transmitted forces. It has been shown that older animal cells display altered actin turnover that may contribute to both impaired migratory capacity and mechano-amplification of signals (Kasper et al. 2009). With respect to tissue engineering, the primary stability of scaffolds and matrices is important but this may be less relevant for in situ guided regeneration. Here, the stiffness and rigidity may be more important for either the maintenance of cellular stemness or the induction of differentiation and morphogenesis (Gilbert et al. 2010). Aging modifies ECM and aged ECM impairs the regenerative potential of precursors while young ECM can rescue aging phenomena in precursor cells (Sun et al. 2011). Therefore, accumulated knowledge about the aging process should be incorporated into future strategies for in situ guided tissue regeneration. Future research will have to demonstrate, whether or not age-related changes in mechanosensitivity and migratory capacity are reversible at least to some extent and if such changes can be targeted within therapeutic strategies in the elderly.

Stem cell niche functional cues

Stem cell adhesion in the niche is mediated by a variety of adhesion molecules and structures but the exact molecular composition of niches is only known from some examples. Moreover, the molecular composition depends on the type of tissue, e.g. epithelially organised structures, vesselassociated niches and stromal niches. Cadherins and adherence junction molecules may keep the stem cells attached to the hub, while integrin binding attaches them to basal membranes and ECM and at the same time this mediates signalling that influences the stemness status (Marthiens et al. 2010). In addition, hub cells secrete proteins that inhibit morphogenesis and maintain the stemness and quiescence status of stem cells (Fuchs et al. 2004). As we know from Drosophila, BMP-related ligands for the TGFb-signalling pathway are good candidates to modulate this stemness maintenance (Sieber et al. 2009; Wagner et al. 2010). Using knockout or inhibitor strategies, one can either deplenish or accumulate stem cells in and from niches and in consequence lose regenerative capacity as has been shown with hematopoetic stem cells and their respective niches. Here, Myc seems to play an important role in regulating the exit from the niche vial e.g.l regulation of integrin and $\mathrm{N}$ cadherin expression (Marthiens et al. 2010). Moreover, subtypes of macrophages like a CD169+ subpopulation may modulate the retention of stem cells in their niches (Chow et al. 2011). Future strategies of in situ guided tissue regeneration should include the specific requirements that lack in situations of aging and disease. Hence, materials should be designed to replace missing adhesion microstructures, to timely liberate missing directive growth and differentiation factors and also to finally deliver antagonists for proliferation and differentiation inhibitors that are characteristic for the aging and diseased organism such as activin, sclerostin and myostatin (see above).

\section{Summary and conclusions}

A vision of in situ guided tissue regeneration strategies has been developed, where smart materials delivering peptide or small molecules with and without regenerative cells can be applied with minimally invasive techniques to enhance endogenous regeneration respecting (stem) cell biology and developmental processes (Gilbert and Blau 2011; Lutolf et al. 2009; Uebersax et al. 2009). Exciting developments in material science are capable of perfectly matching these scenarios using intelligent and functional materials, which can also be designed for perfect timely release of factors involved in regeneration (Astachov et al. 2011; Chen et al. 2010; Di Maggio et al. 2011; Dvir et al. 2011; Gilbert and Blau 2011; Grafahrend et al. 2010; Klinkhammer et al. 2010; Lutolf et al. 2009; Meinel et al. 2009; Votteler et al. 2010). Cellular and organismal aging phenomena in an elderly and diseased target population for regenerative strategies may be serious obstacles for successful treat- 
ment regimens. This has been considerably fostered by recent knowledge about the regulation of regeneration by inhibitory molecules, which when overproduced or prematurely secreted become master principles of (degenerative) disease. There is also, however, accumulating evidence that endogenous regeneration capacity even in old and diseased organisms could be permissively set on scene by neutralization of inhibitors (Morissette et al. 2009; Trivedi et al. 2010). Promising approaches may also be developed using micro-RNA-based strategies, since RNAs have been identified that regulate programs in regenerative cells and aging phenomena (Hackl et al. 2010; Stadler and Ruohola-Baker 2008; Tsai et al. 2010). Taking this shift of paradigms into account, new tailored strategies can be developed for local and systemic modulation of tissue regeneration and healing with a focus on elderly and diseased organisms.

Open Access This article is distributed under the terms of the Creative Commons Attribution Noncommercial License that permits any noncommercial use, distribution and reproduction in any medium, provided the original author(s) and source are credited.

\section{References}

Astachov L, Nevo Z, Aviv M, Vago R (2011) Crystalline calcium carbonate and hydrogels as microenvironment for stem cells. Front Biosci 16:458-471

Atala A, Bauer SB, Soker S, Yoo JJ, Retik AB (2006) Tissueengineered autologous bladders for patients needing cystoplasty. Lancet 367:1241-1246

Bartneck M, Keul HA, Singh S, Czaja K, Bornemann J, Bockstaller M, Möller M, Zwadlo-Klarwasser G, Groll J (2010) Rapid uptake of gold nanorods by primary humanblood phagocytes and immunomodulatory effects of surface chemistry. Am Chem Soc Nano 4:3073-3086

Bedi A, Feeley BT, Williams RJ 3rd (2010) Management of articular cartilage defects of the knee. J Bone Jt Surg Am 92:994-1009

Benthien JP, Schwaninger M, Behrens P (2011) We do not have evidence based methods for the treatment of cartilage defects in the knee. Knee Surg Sports Traumatol Arthrosc 19:543-552

Bernardo ME, Pagliara D, Locatelli F (2011) Mesenchymal stromal cell therapy: a revolution in regenerative medicine? Bone Marrow Transpl (in press)

Bi Y, Ehirchiou D, Kilts TM, Inkson CA, Embree MC, Sonoyama W, Li L, Leet AI, Seo BM, Zhang L et al (2007) Identification of tendon stem/progenitor cells and the role of the extracellular matrix in their niche. Nat Med 13:1219-1227

Blau HM, Pomerantz JH (2011) Re"evolutionary" regenerative medicine. JAMA 305:87-88

Bruellhoff K, Fiedler J, Möller M, Groll J, Brenner RE (2010) Surface coating strategies to prevent biofilm formation on implant surfaces. Int J Artif Organs 33:646-653

Brusnahan SK, McGuire TR, Jackson JD, Lane JT, Garvin KL, O'Kane BJ, Berger AM, Tuljapurkar SR, Kessinger MA, Sharpa JG (2010) Human blood and marrow side population stem cell and Stro-1 positive bone marrow stromal cell numbers decline with age, with an increase in quality of surviving stem cells: correlation with cytokines. Mech Ageing Dev 131:718-722

Burtner CR, Kennedy BK (2010) Progeria syndromes and ageing: what is the connection? Nat Rev Mol Cell Biol 11:567-578

Chen FM, Zhang J, Zhang M, An Y, Chen F, Wu ZF (2010) A review on endogenous regenerative technology in periodontal regenerative medicine. Biomaterials 31:7892-7927

Chen FM, Wu LA, Zhang M, Zhang R, Sun HH (2011) Homing of endogenous stem/progenitor cells for in situ tissue regeneration: promises, strategies, and translational perspectives. Biomaterials 32:3189-3209

Chow A, Lucas D, Hidalgo A, Mendez-Ferrer S, Hashimoto D, Scheiermann C, Battista M, Leboeuf M, Prophete C, van Rooijen $\mathrm{N}$ et al (2011) Bone marrow CD169+ macrophages promote the retention of hematopoietic stem and progenitor cells in the mesenchymal stem cell niche. J Exp Med 208:261-271

Cooper GM, Mooney MP, Gosain AK, Campbell PG, Losee JE, Huard J (2010) Testing the critical size in calvarial bone defects: revisiting the concept of a critical-size defect. Plast Reconstr Surg 125:1685-1692

Cui Q, Botchwey EA (2010) Emerging ideas: treatment of precollapse osteonecrosis using stem cells and growth factors. Clin Orthop Relat Res (in press)

Di Maggio N, Piccinini E, Jaworski M, Trumpp A, Wendt DJ, Martin I (2011) Toward modeling the bone marrow niche using scaffoldbased 3D culture systems. Biomaterials 32:321-329

Docheva D, Padula D, Popov C, Weishaupt P, Pragert M, Miosge N, Hickel R, Bocker W, Clausen-Schaumann H, Schieker M (2010) Establishment of immortalized periodontal ligament progenitor cell line and its behavioural analysis on smooth and rough titanium surface. Eur Cell Mater 19:228-241

Dvir T, Timko BP, Kohane DS, Langer R (2011) Nanotechnological strategies for engineering complex tissues. Nat Nanotechnol 6:13-22

Efimenko A, Starostina E, Kalinina N, Stolzing A (2011) Angiogenic properties of aged adipose derived mesenchymal stem cells after hypoxic conditioning. J Transl Med 9:10

Fan M, Chen W, Liu W, Du GQ, Jiang SL, Tian WC, Sun L, Li RK, Tian H (2010) The effect of age on the efficacy of human mesenchymal stem cell transplantation after a myocardial infarction. Rejuvenation Res 13:429-438

Fehrer C, Brunauer R, Laschober G, Unterluggauer H, Reitinger S, Kloss F, Gully C, Gassner R, Lepperdinger G (2007) Reduced oxygen tension attenuates differentiation capacity of human mesenchymal stem cells and prolongs their lifespan. Aging Cell 6:745-757

Flynn A, O'Brien T (2011) Stem cell therapy for cardiac disease. Expert Opin Biol Ther 11:177-187

Foldager CB, Nielsen AB, Munir S, Ulrich-Vinther M, Soballe K, Bunger C, Lind M (2011) Combined 3D and hypoxic culture improves cartilage-specific gene expression in human chondrocytes. Acta Orthop 82:234-240

Fuchs E, Tumbar T, Guasch G (2004) Socializing with the neighbors: stem cells and their niche. Cell 116:769-778

Garcia-Fuentes M, Meinel AJ, Hilbe M, Meinel L, Merkle HP (2009) Silk fibroin/hyaluronan scaffolds for human mesenchymal stem cell culture in tissue engineering. Biomaterials 30:5068-5076

Gavenis K, Schneider U, Groll J, Schmidt-Rohlfing B (2010) BMP-7loaded PGLA microspheres as a new delivery system for the cultivation of human chondrocytes in a collagen type I gel: the common nude mouse model. Int J Artif Organs 33:45-53

Giardino R, Aldini NN, Fini M, Giavaresi G, Torricelli P (2002) Enhanced guided bone regeneration with a resorbable chamber containing demineralized bone matrix. J Trauma 52:933-937

Giardino R, Nicoli Aldini N, Fini M, Tanzi MC, Fare S, Draghi L, Carpi A, Nicolini A, Giavaresi G (2006) Bioabsorbable scaffold for in situ bone regeneration. Biomed Pharmacother 60:386-392 
Gilbert PM, Blau HM (2011) Engineering a stem cell house into a home. Stem Cell Res Ther 2:3

Gilbert PM, Havenstrite KL, Magnusson KE, Sacco A, Leonardi NA, Kraft P, Nguyen NK, Thrun S, Lutolf MP, Blau HM (2010) Substrate elasticity regulates skeletal muscle stem cell selfrenewal in culture. Science 329:1078-1081

Gomes PS, Fernandes MH (2011) Rodent models in bone-related research: the relevance of calvarial defects in the assessment of bone regeneration strategies. Lab Anim 45:14-24

Grafahrend D, Heffels KH, Moller M, Klee D, Groll J (2010) Electrospun, biofunctionalized fibers as tailored in vitro substrates for keratinocyte cell culture. Macromol Biosci 10:1022-1027

Grafahrend D, Heffels KH, Beer MV, Gasteier P, Moller M, Boehm G, Dalton PD, Groll J (2011) Degradable polyester scaffolds with controlled surface chemistry combining minimal protein adsorption with specific bioactivation. Nat Mater 10:67-73

Grillari J, Grillari-Voglauer R (2010) Novel modulators of senescence, aging, and longevity: small non-coding RNAs enter the stage. Exp Gerontol 45:302-311

Groll J, Fiedler J, Bruellhoff K, Moeller M, Brenner RE (2009) Novel surface coatings modulating eukaryotic cell adhesion and preventing implant infection. Int J Artif Organs 32:655-662

Hackl M, Brunner S, Fortschegger K, Schreiner C, Micutkova L, Muck C, Laschober GT, Lepperdinger G, Sampson N, Berger P et al (2010) miR-17, miR-19b, miR-20a, and miR-106a are down-regulated in human aging. Aging Cell 9:291-296

Hamrick MW, McPherron AC, Lovejoy CO (2002) Bone mineral content and density in the humerus of adult myostatin-deficient mice. Calcif Tissue Int 71:63-68

Hamrick MW, Samaddar T, Pennington C, McCormick J (2006) Increased muscle mass with myostatin deficiency improves gains in bone strength with exercise. J Bone Miner Res 21:477483

Hauzeur JP, Gangji V (2010) Phases 1-3 clinical trials using adult stem cells in osteonecrosis and nonunion fractures. Stem Cells Int 2010:410170

Henderson JH, Ginley NM, Caplan AI, Niyibizi C, Dennis JE (2010) Low oxygen tension during incubation periods of chondrocyte expansion is sufficient to enhance postexpansion chondrogenesis. Tissue Eng Part A 16:1585-1593

Hernigou P, Poignard A, Manicom O, Mathieu G, Rouard H (2005) The use of percutaneous autologous bone marrow transplantation in nonunion and avascular necrosis of bone. J Bone Jt Surg Br 87:896-902

Hildner F, Albrecht C, Gabriel C, Redl H, van Griensven M (2011) State of the art and future perspectives of articular cartilage regeneration: a focus on adipose-derived stem cells and plateletderived products. J Tissue Eng Regen Med (in press)

Hogan MV, Bagayoko N, James R, Starnes T, Katz A, Chhabra AB (2011) Tissue engineering solutions for tendon repair. J Am Acad Orthop Surg 19:134-142

Horner EA, Kirkham J, Wood D, Curran S, Smith M, Thomson B, Yang XB (2010) Long bone defect models for tissue engineering applications: criteria for choice. Tissue Eng Part B Rev 16:263271

Hutmacher DW (2000) Scaffolds in tissue engineeringbone and cartilage. Biomaterials 21:2529-2543

James R, Kumbar SG, Laurencin CT, Balian G, Chhabra AB (2011) Tendon tissue engineering: adipose-derived stem cell and GDF-5 mediated regeneration using electrospun matrix systems. Biomed Mater 6:025011

Jhamb D, Rao N, Milner DJ, Song F, Cameron JA, Stocum DL, Palakal MJ (2011) Network based transcription factor analysis of regenerating axolotl limbs. BMC Bioinform 12:80

Jones E, Yang X (2011) Mesenchymal stem cells and bone regeneration: current status. Injury (in press)
Kajikawa Y, Morihara T, Watanabe N, Sakamoto H, Matsuda K, Kobayashi M, Oshima Y, Yoshida A, Kawata M, Kubo T (2007) GFP chimeric models exhibited a biphasic pattern of mesenchymal cell invasion in tendon healing. J Cell Physiol 210:684-691

Kasper G, Mao L, Geissler S, Draycheva A, Trippens J, Kuhnisch J, Tschirschmann M, Kaspar K, Perka C, Duda GN et al (2009) Insights into mesenchymal stem cell aging: involvement of antioxidant defense and actin cytoskeleton. Stem Cells 27:1288-1297

Keith B, Simon MC (2007) Hypoxia-inducible factors, stem cells, and cancer. Cell 129:465-472

Kikuiri T, Kim I, Yamaza T, Akiyama K, Zhang Q, Li Y, Chen C, Chen W, Wang S, Le AD et al (2010) Cell-based immunotherapy with mesenchymal stem cells cures bisphosphonate-related osteonecrosis of the jaw-like disease in mice. J Bone Miner Res 25:1668-1679

Kim KS, Kang YM, Lee JY, Kim ES, Kim CH, Min BH, Lee HB, Kim JH, Kim MS (2009) Injectable CMC/PEI gel as an in vivo scaffold for demineralized bone matrix. Biomed Mater Eng 19:381-390

Kirker-Head C, Karageorgiou V, Hofmann S, Fajardo R, Betz O, Merkle HP, Hilbe M, von Rechenberg B, McCool J, Abrahamsen L et al (2007) BMP-silk composite matrices heal critically sized femoral defects. Bone 41:247-255

Klinkhammer K, Bockelmann J, Simitzis C, Brook GA, Grafahrend D, Groll J, Moller M, Mey J, Klee D (2010) Functionalization of electrospun fibers of poly(epsilon-caprolactone) with star shaped NCO-poly(ethylene glycol)-stat-poly(propylene glycol) for neuronal cell guidance. J Mater Sci Mater Med 21:2637-2651

Koncarevic A, Cornwall-Brady M, Pullen A, Davies M, Sako D, Liu J, Kumar R, Tomkinson K, Baker T, Umiker B et al (2010) A soluble activin receptor type IIb prevents the effects of androgen deprivation on body composition and bone health. Endocrinology 151:4289-4300

Krebs MD, Sutter KA, Lin AS, Guldberg RE, Alsberg E (2009) Injectable poly(lactic-co-glycolic) acid scaffolds with in situ pore formation for tissue engineering. Acta Biomater 5:2847-2859

Kretlow JD, Klouda L, Mikos AG (2007) Matrices and scaffolds for drug delivery in tissue engineering.Adv Drug Delivery Rev 59:263-273

Laschober GT, Brunauer R, Jamnig A, Singh S, Hafen U, Fehrer C, Kloss F, Gassner R, Lepperdinger G (2011) Age-specific changes of mesenchymal stem cells are paralleled by upregulation of CD106 expression as a response to an inflammatory environment. Rejuvenation Res (in press)

Lee K, Goodman SB (2009) Cell therapy for secondary osteonecrosis of the femoral condyles using the Cellect DBM System: a preliminary report. J Arthroplast 24:43-48

Lee KY, Mooney DJ (2001) Hydrogels for tissue engineering. Chem Rev 101:1869-1879

Levi B, Longaker MT (2011) Concise review: adipose-derived stromal cells for skeletal regenerative medicine. Stem Cells 29:576-582

Li SC, Acevedo J, Schwartz PH, Wang L, Jiang H, Luo J, Pestell RG, Loudon WG, Chang AC (2011) Mechanisms for progenitor cellmediated repair for ischemic heart injury. Curr Stem Cell Res Ther (in press)

Liedert A, Kaspar D, Blakytny R, Claes L, Ignatius A (2006) Signal transduction pathways involved in mechanotransduction in bone cells. Biochem Biophys Res Commun 349:1-5

Liedert A, Wagner L, Seefried L, Ebert R, Jakob F, Ignatius A (2010) Estrogen receptor and Wnt signaling interact to regulate early gene expression in response to mechanical strain in osteoblastic cells. Biochem Biophys Res Commun 394:755-759

Liu CF, Aschbacher-Smith L, Barthelery NJ, Dyment N, Butler D, Wylie C (2011) What we should know before using tissue engineering techniques to repair injured tendons: a developmental biology perspective. Tissue Eng Part B Rev (in press) 
Lutolf MP, Hubbell JA (2005) Synthetic biomaterials as instructiveextracellular microenvironments formorphogenesis in tissue engineering. Nature Biotechnol 21:47-55

Lutolf MP, Raeber GP, Zisch AH, Tirelli N, Hubbell JA (2003) Cellresponsivesynthetic hydrogels. Adv Mater 15:888-892

Lutolf MP, Gilbert PM, Blau HM (2009) Designing materials to direct stem-cell fate. Nature 462:433-441

Malchesky PS (2011) Artificial organs 2010: a year in review. Artif Organs 35:316-350

Marthiens V, Kazanis I, Moss L, Long K, Ffrench-Constant C (2010) Adhesion molecules in the stem cell niche-more than just staying in shape? J Cell Sci 123:1613-1622

McCusker C, Gardiner DM (2011) The axolotl model for regeneration and aging research: a mini-review. Gerontology (in press)

Meinel AJ, Kubow KE, Klotzsch E, Garcia-Fuentes M, Smith ML, Vogel V, Merkle HP, Meinel L (2009) Optimization strategies for electrospun silk fibroin tissue engineering scaffolds. Biomaterials 30:3058-3067

Menasche P (2011) Cardiac cell therapy: lessons from clinical trials. J Mol Cell Cardiol 50:258-265

Mertsching H, Walles T (2009) Europe's advanced therapy medicinal products: chances and challenges. Expert Rev Med Devices 6:109-110

Mertsching H, Schanz J, Steger V, Schandar M, Schenk M, Hansmann J, Dally I, Friedel G, Walles T (2009) Generation and transplantation of an autologous vascularized bioartificial human tissue. Transplantation 88:203-210

Meyer EG, Buckley CT, Thorpe SD, Kelly DJ (2010) Low oxygen tension is a more potent promoter of chondrogenic differentiation than dynamic compression. J Biomech 43:2516-2523

Mohyeldin A, Garzon-Muvdi T, Quinones-Hinojosa A (2010) Oxygen in stem cell biology: a critical component of the stem cell niche. Cell Stem Cell 7:150-161

Morissette MR, Stricker JC, Rosenberg MA, Buranasombati C, Levitan EB, Mittleman MA, Rosenzweig A (2009) Effects of myostatin deletion in aging mice. Aging Cell 8:573-583

Muller I, Vaegler M, Holzwarth C, Tzaribatchev N, Pfister SM, Schutt B, Reize P, Greil J, Handgretinger R, Rudert M (2008) Secretion of angiogenic proteins by human multipotent mesenchymal stromal cells and their clinical potential in the treatment of avascular osteonecrosis. Leukemia 22:2054-2061

Nishikawa K, Nakashima T, Takeda S, Isogai M, Hamada M, Kimura A, Kodama T, Yamaguchi A, Owen MJ, Takahashi S et al (2010) Maf promotes osteoblast differentiation in mice by mediating the age-related switch in mesenchymal cell differentiation. J Clin Invest 120:3455-3465

Noth U, Reichert J, Reppenhagen S, Steinert A, Rackwitz L, Eulert J, Beckmann J, Tingart M (2007) Cell based therapy for the treatment of femoral head necrosis. Orthopade 36:466-471

Omori K, Nakamura T, Kanemaru S, Asato R, Yamashita M, Tanaka S, Magrufov A, Ito J, Shimizu Y (2005) Regenerative medicine of the trachea: the first human case. Ann Otol Rhinol Laryngol 114:429-433

Ozcivici E, Luu YK, Adler B, Qin YX, Rubin J, Judex S, Rubin CT (2010) Mechanical signals as anabolic agents in bone. Nat Rev Rheumatol 6:50-59

Pennesi G, Scaglione S, Giannoni P, Quarto R (2011) Regulatory influence of scaffolds on cell behavior: how cells decode biomaterials. Curr Pharm Biotechnol 12:151-159

Perren SM, Cordey J, Rahn BA, Gautier E, Schneider E (1988) Early temporary porosis of bone induced by internal fixation implants. A reaction to necrosis, not to stress protection? Clin Orthop Relat Res 139-151

Pollina EA, Brunet A (2011) Epigenetic regulation of aging stem cells. Oncogene (in press)

Rouwkema J, Gibbs S, Lutolf MP, Martin I, Vunjak-Novakovic G, MaldaIn J (2011 In vitro platforms for tissue engineering: implications for basic research and clinical translation. J Tissue Eng Regen Med 5:e164-e167

Sahin E, Depinho RA (2010) Linking functional decline of telomeres, mitochondria and stem cells during ageing. Nature 464:520-528

Saxon LK, Robling AG, Castillo AB, Mohan S, Turner CH (2007) The skeletal responsiveness to mechanical loading is enhanced in mice with a null mutation in estrogen receptor-beta. Am J Physiol Endocrinol Metab 293:E484-E491

Schilling T, Kuffner R, Klein-Hitpass L, Zimmer R, Jakob F, Schutze N (2008) Microarray analyses of transdifferentiated mesenchymal stem cells. J Cell Biochem 103:413-433

Schuurman W, Khristov V, Pot MW, van Weeren PR, Dhert WJA, Malda J (2011 Bioprinting of hybrid tissue constructs with tailorable mechanical properties. Biofabrication 3:021001

Seefried L, Mueller-Deubert S, Schwarz T, Lind T, Mentrup B, Kober M, Docheva D, Liedert A, Kassem M, Ignatius A et al (2010) A small scale cell culture system to analyze mechanobiology using reporter gene constructs and polyurethane dishes. Eur Cell Mater 20:344-355

Shekaran A, Garcia AJ (2011) Extracellular matrix-mimetic adhesive biomaterials for bone repair. J Biomed Mater Res A 96:261-272

Shore EM, Kaplan FS (2010) Inherited human diseases of heterotopic bone formation. Nat Rev Rheumatol 6:518-527

Sieber C, Kopf J, Hiepen C, Knaus P (2009) Recent advances in BMP receptor signaling. Cytokine Growth Factor Rev 20:343-355

Singer NG, Caplan AI (2011) Mesenchymal stem cells: mechanisms of inflammation. Annu Rev Pathol 6:457-478

Stadler BM, Ruohola-Baker H (2008) Small RNAs: keeping stem cells in line. Cell 132:563-566

Sun Y, Li W, Lu Z, Chen R, Ling J, Ran Q, Jilka RL, Chen XD (2011) Rescuing replication and osteogenesis of aged mesenchymal stem cells by exposure to a young extracellular matrix. FASEB J (in press)

Taguchi Y, Amizuka N, Nakadate M, Ohnishi H, Fujii N, Oda K, Nomura S, Maeda T (2005) A histological evaluation for guided bone regeneration induced by a collagenous membrane. Biomaterials 26:6158-6166

Temiyasathit S, Jacobs CR (2010) Osteocyte primary cilium and its role in bone mechanotransduction. Ann NY Acad Sci 1192:422-428

Toben D, Schroeder I, El Khassawna T, Mehta M, Hoffmann JE, Frisch JT, Schell H, Lienau J, Serra A, Radbruch A et al (2011) Fracture healing is accelerated in the absence of the adaptive immune system. J Bone Miner Res 26:113-124

Trivedi R, Goswami R, Chattopadhyay N (2010) Investigational anabolic therapies for osteoporosis. Expert Opin Investig Drugs 19:995-1005

Tsai ZY, Singh S, Yu SL, Kao LP, Chen BZ, Ho BC, Yang PC, Li SS (2010) Identification of microRNAs regulated by activin $A$ in human embryonic stem cells. J Cell Biochem 109:93-102

Tyndall A, Houssiau FA (2010) Mesenchymal stem cells in the treatment of autoimmune diseases. Ann Rheum Dis 69:14131414

Uebersax L, Merkle HP, Meinel L (2009) Biopolymer-based growth factor delivery for tissue repair: from natural concepts to engineered systems. Tissue Eng Part B Rev 15:263-289

Uskokovic V, Uskokovic DP (2011) Nanosized hydroxyapatite and other calcium phosphates: chemistry of formation and application as drug and gene delivery agents. J Biomed Mater Res B Appl Biomater 96:152-191

van Dinther M, Visser N, de Gorter DJ, Doorn J, Goumans MJ, de Boer J, ten Dijke P (2010) ALK2 R206H mutation linked to fibrodysplasia ossificans progressiva confers constitutive activity to the BMP type I receptor and sensitizes mesenchymal cells to BMP-induced osteoblast differentiation and bone formation. $\mathrm{J}$ Bone Miner Res 25:1208-1215

Volkmer E, Drosse I, Otto S, Stangelmayer A, Stengele M, Kallukalam BC, Mutschler W, Schieker M (2008) Hypoxia in 
static and dynamic 3D culture systems for tissue engineering of bone. Tissue Eng Part A 14:1331-1340

Volkmer E, Kallukalam BC, Maertz J, Otto S, Drosse I, Polzer H, Bocker W, Stengele M, Docheva D, Mutschler W et al (2010) Hypoxic preconditioning of human mesenchymal stem cells overcomes hypoxia-induced inhibition of osteogenic differentiation. Tissue Eng Part A 16:153-164

Votteler M, Kluger PJ, Walles H, Schenke-Layland K (2010) Stem cell microenvironments-unveiling the secret of how stem cell fate is defined. Macromol Biosci 10:1302-1315

Wagner DO, Sieber C, Bhushan R, Borgermann JH, Graf D, Knaus P (2010) BMPs: from bone to body morphogenetic proteins. Sci Signal 3:mr1

Walles T, Biancosino C, Zardo P, Macchiarini P, Gottlieb J, Mertsching $H$ (2005) Tissue remodeling in a bioartificial fibromuscular patch following transplantation in a human. Transplantation 80:284-285

Warden SJ (2009) Development and use of animal models to advance tendinopathy research. Front Biosci 14:4588-4597

Wenk E, Murphy AR, Kaplan DL, Meinel L, Merkle HP, Uebersax L (2010) The use of sulfonated silk fibroin derivatives to control binding, delivery and potency of FGF-2 in tissue regeneration. Biomaterials 31:1403-1413
Wenk E, Merkle HP, Meinel L (2011) Silk fibroin as a vehicle for drug delivery applications. J Control Release 150:128-141

Wu KH, Chan CK, Tsai C, Chang YH, Sieber M, Chiu TH, Ho M, Peng CT, Wu HP, Huang JL (2011a) Effective treatment of severe steroidresistant acute graft-versus-host disease with umbilical cord-derived mesenchymal stem cells. Transplantation (in press)

Wu M, Fannin J, Rice KM, Wang B, Blough ER (2011b) Effect of aging on cellular mechanotransduction. Ageing Res Rev 10:1-15

Xiao L, Sobue T, Esliger A, Kronenberg MS, Coffin JD, Doetschman T, Hurley MM (2010) Disruption of the Fgf2 gene activates the adipogenic and suppresses the osteogenic program in mesenchymal marrow stromal stem cells. Bone 47:360-370

Yew TL, Chiu FY, Tsai CC, Chen HL, Lee WP, Chen YJ, Chang MC, Hung SC (2011) Knockdown of p21(Cip1/Wafl) enhances proliferation, the expression of stemness markers, and osteogenic potential in human mesenchymal stem cells. Aging Cell 10:349-361

Zhang Y, Wang B, Zhang WJ, Zhou G, Cao Y, Liu W (2010) Enhanced proliferation capacity of porcine tenocytes in low O2 tension culture. Biotechnol Lett 32:181-187

Zhao S, Wehner R, Bornhauser M, Wassmuth R, Bachmann M, Schmitz M (2010) Immunomodulatory properties of mesenchymal stromal cells and their therapeutic consequences for immunemediated disorders. Stem Cells Dev 19:607-614 